ISSN Cetak 2303-1433

ISSN Online: 2579-7301

\title{
HUBUNGAN UMUR DAN STATUS GIZI DENGAN KADAR GULA DARAH PENDERITA DIABETES MELITUS TIPE II
}

\author{
Eny Masruroh \\ Sekolah Tinggi Ilmu Kesehatan "Hutama Abdi Husada" Tulungagung \\ enystikesta@gmail.com
}

\begin{abstract}
Diabetes Mellitus (DM) type II is the most common type. Type II DM can increase significantly as people's lifestyle changes and increased age over 40 years and obesity problems are characterized by an increase in body mass index (BMI) $\geq 25 \mathrm{Kg} / \mathrm{m} 2$. Excessive BMM can cause blood sugar levels to increase because the body becomes resistant to insulin. This study to determine the relationship between age and nutritional status based on BMI with blood sugar levels in patients with type II DM in Poly Diseases In RSUD dr. Iskak Tulungagung. The data were collected on 19-20 April 2017. The research design used correlational analytic. Population of all DM type II patients in Poly Disease In RSUD dr. Iskak Tulungagung using Quota Sampling technique with 30 respondents. Taking IMT variable data using scales and microtoa scales. While the variable blood sugar levels using glucotest stick. Then the data were analyzed by paired $t$ test. The results of this study on average BMI $25.77 \mathrm{Kg} / \mathrm{m} 2$ with an average blood sugar levels 213,23 $\mathrm{mg} / \mathrm{dL}$. From the statistical test results show there is a relationship between age with blood sugar levels indicated $p$ value $=0.00$.begitu also on the test of nutritional status with blood sugar levels in patients with type II DM in the Poly Diseases In RSUD dr. Tulungagung Iskak shown with $p$ value $=0,000$ and $\alpha 0.05$ which means $p<0.05$ which means there is a correlation between the two. Based on the research, there is a relationship between age and nutritional status with blood sugar levels it is recommended for respondents with excess BMI can maintain ideal body weight and in patients with type II DM at age more than 40 years more maintain a healthy lifestyle that can prevent complications diabetes due to high blood sugar levels.
\end{abstract}

\section{Keywords: Age, Nutrition Status based on IMT, Blood Sugar Level, DM}

\section{PENDAHULUAN}

Diabetes Melitus (DM) merupakan suatu penyakit metabolisme yang bersifat kronis yang ditandai dengan adanya peningkatan kadar gula (glukosa) di dalam darah (hyperglikemia) yang disebabkan oleh karena adanya ketidakseimbangan antara suplai dengan kebutuhan insulin. Insulin di dalam tubuh akan bertindak sebagai fasilitator yang diperlukan untuk memfasilitasi masuknya glukosa dalam sel agar dapat digunakan untuk metabolisme dan pertumbuhan sel (Tarwoto, 2011).

Menurut American Diabetes Association (2015), Diabetes Melitus dapat diklasifikasikan menjadi beberapa tipe yakni, Diabetes Melitus tipe I, Diabetes Melitus tipe II, Diabetes Melitus
Gestasional, dan Diabetes Melitus tipe lain. Dari beberapa tipe yang ada, Diabetes Melitus tipe II merupakan tipe DM yang paling banyak di temukan yakni lebih dari 90-95\%. Menurut Sornoza (2011), Diabetes Melitus tipe II akan meningkat secara signifikan seiring dengan perubahan gaya hidup masyarakat (pola makan yang salah dan rendahnya aktivitas fisik) umur dan masalah obesitas. Kecenderungan DM Tipe II terjadi pada umur lebih dari 40 tahun.

Status Gizi adalah keadaan tubuh yang merupakan hasil akhir dari keseimbangan antara zat gizi yang masuk ke dalam tubuh dan penggunaannya. Salah satu cara untuk memantau status gizi orang dewasa adalah dengan mengukur Indeks Massa Tubuh 
(IMT). Indeks massa tubuh merupakan indikator yang paling sering digunakan dan praktis untuk mengukur tingkat populasi berat badan lebih dan obesitas pada orang dewasa (Sugondo, 2006).

Semakin meningkatnya umur dan tingkat obesitas merupakan faktor resiko utama peningkatan kadar gula darah selain dari akibat genetika. Menurut Kariadi (2009), faktor resiko terjadinya Diabetes Melitus salah satunya adalah obesitas. Tertimbunnya lemak tubuh yang berlebih dapat menyebabkan respon sel beta terhadap glukosa darah menjadi berkurang. Selain itu, reseptor insulin pada sel target menjadi resisten dan jumlahnya berkurang sehingga insulin dalam darah tidak dapat dimanfaatkan. Pada orang yang mengalami kelebihan berat badan, kadar leptin di dalam tubuh akan meningkat.Leptin merupakan salah satu adipokin yang memiliki peran dalam menjaga homeostasis energi dalam tubuh. Leptin yang meningkat ini kemudian akan menghambat fosfolirasi insulin reseptor substrate $I$ akan menyebabkan peningkatan kadar gula dalam darah yang disebabkan dapat hambatan ambilan glukosa (D'Adamo, 2008).

Menurut International of Diabetic Federation tingkat prevalensi global penderita DM pada tahun 2014 sebesar $8,3 \%$ dari keseluruhan penduduk di dunia dan mengalami peningkatan pada tahun 2014 menjadi 387 juta kasus. Indonesia merupakan negara yang menempati urutan ke 7 dengan penderita DM sejumlah 8,5 juta penderita setelah Cina, India, Amerika Serikat, Brazil, Rusia, dan Mexico. Sedangkan menurut Perkumpulan Endokrinologi (PERKENI), di Indonesia jumlah penderita Diabetes Melitus pada tahun 2015 telah mencapai 9,1 juta orang.

Dinas Kesehatan Provinsi Jawa Timur mencatat bahwa di tahun 2012 sebanyak 102.399 kasus Diabeus mellitus dan merupakan penyakit terbanyak nomor dua setelah hipertensi. Sedangkan di Kabupaten Tulungagung, jumlah penderita Diabetes Melitus tahun 2015 yang tercatat di Dinas Kesehatan Kabupaten Tulungagung sejumlah 10.572 kasus, dengan jumlah tertinggi kasus Diabetes Melitus dirawat di RSUD dr. Iskak Tulungagung.

Masalah kesehatan yang terjadi karena penyakit Diabetes Melitus, apabila kadar gula darahnya yang tinggi tidak dikelola dengan baik dapat menimbulkan berbagai macam komplikasi. Beberapa penyakit yang dapat dikeluhkan diantaranya gangguan penglihatan, penyakit jantung, gangguan ginjal, luka sulit sembuh dan gangren (membusuk). Selain itu, penderita DM tipe II dengan kadar gula darah yang tidak terkendali memiliki resiko kematian. Selain kematian juga sebagai penyakit yang akan diderita seumur hidup sehingga memerlukan biaya perawatan kesehatan yang sangat besar (IDF, 2011).

Melihat bahwa Diabetes Melitus akan memberikan dampak terhadap kualitas sumber daya manusia dan peningkatan biaya kesehatan yang cukup besar, maka sangat diperlukan program pengendalian Diabetes Melitus Tipe II. Diabetes Melitus Tipe II bisa dicegah, ditunda kedatangannya atau dihilangkan dengan mengendalikan faktor resiko (Kemenkes, 2010). Menurut Irawan (2010), sebesar 22,6\% kasus Diabetes Melitus Tipe II di dalam populasi dapat dicegah dengan melakukan pola preventif dan kuratif. Maka dari itu, program olahraga yang baik, benar, teratur dan terukur dapat membantu menstabilkan kadar gula darah, mengurangi kebutuhan insulin dan obatobatan, serta memelihara berat badan (PERKENI, 2011).

Dari uraian di atas, maka peneliti berminat untuk melakukan penelitian tentang hubungan antara umur dan status gizi dengan kadar gula darah pada penderita Diabetes Melitus tipe II di Poli Penyakit Dalam RSUD dr. Iskak Tulungagung.

\section{METODE PENELITIAN}

Penelitian dilaksanakan di Poli Penyakit Dalam RSUD dr. Iskak 
Tulungagung pada tanggal 19-20 April 2017. Desain penelitian yang digunakan adalah analitik korelasional menggunakan pendekatan melalui penelitian cross sectional. Populasi penelitian ini adalah semua penderita Diabetes Melitus yang datang berkunjung ke Poli Penyakit Dalam RSUD dr. Iskak Tulungagung. Jumlah sampel yang diambil sebanyak 30 responden yang memnuhi kriteria inklusi yaitu penderita yang bersedia menjadi responde, berusia $\geq 30$ tahun, sudah minum OHO (Obat Hipoglikemi Oral), dan penderita yang sadar penuh dan mampu berkomunikasi.

Teknik pengumpulan data yang dilakukan Setelah mendapatkan balasan dari RSUD dr. Iskak Tulungagung, kemudian menyerahkan surat ke Karu Poli Penyakit Dalam. Setelah mendapatkan ijin, memberi penjelasan dan meminta persetujuan calon responden menjadi responden penelitian. kemudian, melakukan pengambilan data pada responden.

Jenis data yang dikumpulkan adalah data umum dan data khusus. Data umum meliputi, jenis kelamin, dan tingkat pendidikan. Sedangkan data khusus meliputi umur, indeks massa tubuh dan kadar gula darah responden. Pengumpulan data dilakukan dengan menggunakan timbangan injak untuk pengukuran berat badan, mikrotoise untuk pengukuran tinggi badan, dan glucotest stick untuk pengukuran kadar gula darah.

Setelah dilakukan penelitian dan data terkumpul, dilakukan analisis data dengan menggunakan SPSS 16.0 for windows. Analisis data yang digunakan adalah analisis univariat untuk melihat distribusi dengan melihat prosentase masing-masing dan uji statistik Paired t test dengan skala data interval untuk menguji hubungan umur (variabel independen) dengan kadar gula darah (variabel dependen), dan status gizi (variabel independen) dengan kadar gula darah (variabel dependen) pada penderita Diabetes Melitus tipe II.
Karakteristik sampel

1. Jenis Kelamin

Data distribusi jenis kelamin responden dapat dilihat pada tabel 1:

Tabel 1. Distribusi Jenis Kelamin Responden

\begin{tabular}{ccc}
\hline Jenis Kelamin & $\mathrm{N}$ & Prosentase $(\%)$ \\
\hline Laki-laki & 14 & 46,67 \\
Perempuan & 16 & 53,33 \\
\hline Total & 30 & 100 \\
\hline
\end{tabular}

Berdasarkan tabel 1 di atas dapat dijelaskan bahwa dari 30 responden sebagian besar berjenis kelamin perempuan yaitu sebanyak 16 responden $(53,33 \%)$.

2. Tingkat Pendidikan

Data distribusi tingkat pendidikan responden dapat dilihat pada tabel 2:

Tabel 2. Distribusi Tingkat Pendidikan Responden

\begin{tabular}{ccc}
\hline $\begin{array}{c}\text { Tingkat } \\
\text { Pendidikan }\end{array}$ & N & Prosentase (\%) \\
\hline Tidak Sekolah & 0 & 0 \\
SD & 11 & 36,67 \\
SMP & 6 & 20 \\
SMA & 7 & 23,33 \\
Perguruan & 6 & 20 \\
Tinggi & & 100 \\
\hline Total & 30 &
\end{tabular}

Berdasarkan tabel 2 di atas dapat dijelaskan bahwa dari 30 responden hampir setengahnya berpendidikan SD yaitu sebanyak 11 responden $(36,67$ $\%)$.

3. Umur

Tabel 3. Distribusi umur responden Responden

\begin{tabular}{ccccc}
\hline N & Min & Max & $\begin{array}{c}\text { Mean } \\
\text { umur }\end{array}$ & $\begin{array}{c}\text { Standar } \\
\text { Deviasi }\end{array}$ \\
\hline 30 & 32 & 81 & 57 & 1,1974 \\
\hline
\end{tabular}

Berdasarkan tabel 3 diatas rata-rata umur responden adalah 57 tahun 
4. Status Gizi Berdasarkan Indeks Massa Tubuh

Data distribusi status gizi berdasarkan indeks massa tubuh responden dapat dilihat pada tabel 4:

Tabel 4. Distribusi Status Gizi

Berdasarkan Indeks Massa Tubuh Responden

\begin{tabular}{ccccc}
\hline N & Min & Max & $\begin{array}{c}\text { Mean } \\
\text { Status } \\
\text { Gizi } \\
\text { (IMT) }\end{array}$ & $\begin{array}{c}\text { Standar } \\
\text { Deviasi }\end{array}$ \\
\hline 30 & 18 & 42 & 25,77 & 4,725 \\
\hline
\end{tabular}

Berdasarkan tabel 4 di atas dapat menunjukkan bahwa dari 30 responden, rata-rata status gizi responden berdasarkan indeks massa tubuh (IMT) adalah $25,77 \mathrm{Kg} / \mathrm{m}^{2}$ yang menunjukkan status gizi obesitas.

5. Kadar Gula Darah

Data distribusi kadar gula darah responden dapat dilihat pada tabel 5:

Tabel 5. Distribusi Kadar Gula Darah Responden

\begin{tabular}{|c|c|c|c|c|}
\hline N & Min & Max & Mean & $\begin{array}{c}\text { Standar } \\
\text { Deviasi }\end{array}$ \\
\hline 30 & 111 & 385 & 213,23 & 69,658 \\
\hline
\end{tabular}

Berdasarkan tabel 5 di atas dapat menunjukkan bahwa dari 30 responden, rata-rata kadar gula darah responden adalah 213,23 $\mathrm{mg} / \mathrm{dL}$ yang menunjukkan kadar gula darah tinggi.

\section{PEMBAHASAN}

\section{Umur}

Berdasarkan tabel 3 menunjukkan bahwa dari 30 responden menunjukan bahwa rata-rata umur responden adalah 57 tahun.

Menurut Arief (2008), dengan adanya peningkatan umur, maka intoleransi terhadap glukosa akan mengalami peningkatan. Para ahli juga sepakat, bahwa resiko terkena penyakit Diabetes Melitus tipe II akan meningkat mulai usia 45 tahun ke atas. Semakin bertambahnya usia maka individu akan mengalami penyusutan sel $\beta$ pankreas yang progresif, sehingga hormon yang dihasilkan terlalu sedikit dan menyebabkan kadar glukosa naik.

Status Gizi Berdasarkan Indeks Massa Tubuh pada Penderita Diabetes Melitus Tipe II

Berdasarkan tabel 4 dapat menunjukkan bahwa dari 30 responden, rata-rata status gizi responden berdasarkan indeks massa tubuh (IMT) adalah 25,77 $\mathrm{Kg} / \mathrm{m}^{2}$ yang menunjukkan status gizi obesitas.

Menurut Sugondo (2006), indeks massa tubuh merupakan indikator yang paling sering digunakan dan praktis untuk mengukur tingkat populasi berat badan lebih dan obesitas pada orang dewasa. Menurut Mc. Wright (2008), timbunan lemak bebas yang tinggi dapat menyebabkan meningkatnya up-take (pengambilan) sel terhadap asam lemak bebas dan memacu oksidasi lemak yang pada akhirnya akan menghambat penggunaan glukosa dalam otot. Ada beberapa faktor yang dapat mempengaruhi indeks massa tubuh seseorang diantaranya adalah usia dan jenis kelamin (Yunan, 2014).

Apabila dikaitkan dengan faktor umur didapatkan hasil bahwa dari 30 responden rata-rata umur responden adalah 57 tahun.

Berdasarkan penelitian yang telah dilakukan oleh Kantachuvessiri, Sirvichayakul, Kaew Kungwal, Tungtrochitr, dan Lotrakul pada tahun 2005 menunjukkan bahwa terdapat hubungan yang signifikan antara usia yang lebih tua dengan IMT, terutama kategori obesitas dimana subjek penelitian pada kelompok usia 40-49 tahun dan 5059 tahun memiliki risiko lebih tinggi mengalami obesitas dibandingkan kelompok usia kurang dari 40 tahun. Hal 
ini diperkuat dengan teori D'adamo (2008), bahwa faktor risiko DM muncul setelah usia 45 tahun. Hal ini karena orang pada usia ini kurang aktif, berat badan bertambah, massa otot berkurang dan akibat proses menua yang mengakibatkan penyusutan sel-sel beta yang progresif.

Berdasarkan fakta dan teori yang ada terdapat kesesuaian dalam penelitian ini, bahwa usia di atas 45 tahun memiliki kecenderungan berisiko mengalami peningkatan indeks massa tubuh. Hal ini dapat diakibatkan oleh pola makan dan gaya hidup yang kurang baik, serta pada umumnya aktivitas fisik sudah mulai berkurang.

Selain umur, indeks massa tubuh juga dapat dipengaruhi oleh jenis kelamin. Dari 30 responden, sebanyak 14 responden laki-laki memiliki rata-rata indeks masaa tubuh $25,3 \mathrm{Kg} / \mathrm{m}^{2}$ yang menunjukkan status gizi obesitas. Sedangkan dari 16 responden perempuan memiliki rata-rata indeks massa tubuh $27,8 \mathrm{Kg} / \mathrm{m}^{2}$ yang menunjukkan status gizi obesitas.

Perempuan lebih banyak mengalami overweight atau obesitas, dimana laki-laki memiliki massa otot lebih banyak dan menggunakan massa otot yang lebih banyak daripada perempuan dikarenakan aktivitas yang lebih dan pembakaran kalori oleh otot pada laki-laki lebih banyak dibandingkan perempuanhal ini disampaikan oleh penelitian yang dilakukan oleh Theresia (2012), Kelebihan energi tejadi bila konsumsi energi melalui makanan melebihi energi yang dikeluarkan, akibatnya akan terjadi berat badan lebih atau kegemukan (Almatsier, 2009).

Terdapat kesesuaian antara fakta dan teori yang ada di atas, bahwa jenis kelamin dapat berpengaruh terhadap indeks massa tubuh seseorang dimana perempuan berkecenderungan memiliki indeks massa tubuh berlebih daripada laki-laki. Sehingga pada penelitian ini pun lebih banyak dijumpai responden perempuan yang memiliki indeks massa tubuh berlebih daripada responden lakilaki.

\section{Kadar Gula Darah Pada Penderita} Diabetes Melitus Tipe II

Berdasarkan tabel 5 dapat menunjukkan bahwa dari 30 responden, rata-rata kadar gula darah responden adalah 213,23 mg/dL yang menunjukkan kadar gula darah tinggi.

Menurut Dorland (2010), kadar gula darah adalah jumlah kandungan glukosa di dalam plasma darah. Menurut D'Adamo (2008), Orang yang mengalami kelebihan berat badan, kadar leptin dalam tubuhnya akan meningkat, Leptin menghambat fosfolirasi insulin reseptor substrate $I$ yang menghambat ambilan glukosa sehingga terjadi peningkatan kadar gula dalam darah. Berdasarkan penelitian yang dilakukan oleh Miftahul Adnan, Tatik Mulyati, dan Joko Teguh Isworo tahun 2013 menyatakan bahwa jenis kelamin, umur, dan tingkat pendidikan berpengaruh terhadap kejadian Diabetes Melitus tipe II.

Apabila dikaitkan dengan umur, ternyata didapatkan hasil bahwa dari 30 responden rata-rata umur responden adalah 57 tahun.

Menurut Arief (2008), dengan adanya peningkatan umur maka intoleransi terhadap glukosa akan mengalami peningkatan. Para ahli juga sepakat, bahwa resiko terkena penyakit Diabetes Melitus tipe II akan meningkat mulai usia 45 tahun ke atas. Semakin bertambahnya usia maka individu akan mengalami penyusutan sel $\beta$ pankreas yang progresif, sehingga hormon yang dihasilkan terlalu sedikit dan menyebabkan kadar glukosa naik.

Fakta di atas sesuai dengan teori tersebut, bahwa ternyata rata-rata umur responden yang lebih dari 40 tahun memiliki kadar gula darah rata-rata 213,3 $\mathrm{mg} / \mathrm{dL}$ atau kadar gula darah tinggi.

Berdasarkan sebaran penderita diabetes melitus berdasarkan jenis kelamin dapat dijelaskan bahwa dari 30 responden 16 responden berjenis kelamin 
perempuan dan 14 responden berjenis kelamin laki-laki.

Jenis kelamin merupakan salah satu faktor yang berhubungan dengan terjadinya diabetes melitus. Menurut Imam Soeharto (2005), penyakit Diabetes Melitus sebagian besar dapat dijumpai pada perempuan dibandingkan laki-laki. Hal ini disebabkan karena perempuan memiliki LDL atau kolesterol jahat tingkat trigliserida yang lebih tinggi dibandingkan laki-laki dan juga terdapat perbedaan dalam melakukan semua aktivitas dan gaya hidup sehari-hari. Selain itu, peningkatan kadar lipid (lemak darah) pada perempuan lebih tinggi dibandingkan laki-laki. Sehingga perempuan memiliki kecenderungan lebih tinggi mengalami peningkatan kadar gula darah daripada laki-laki.

Terdapat kesesuaian antara fakta dan teori di atas, bahwa secara epidemiologi penyakit Diabetes Melitus tipe II lebih banyak dijumpai pada perempuan daripada laki-laki. Hal ini dapat terjadi karena subjek penelitian lebih banyak perempuan $(53,3 \%)$.

Sebaran penderita Diabetes Melitus berdasarkan tingkat pendidikan dapat dijelaskan bahwa dari 30 responden hampir setengahnya berpendidikan SD yaitu sebanyak 11 responden $(36,67 \%)$.

Tingkat pendidikan merupakan salah satu unsur terpenting yang dapat mempengaruhi penerimaan informasi. Pada penderita dengan pendidikan rendah dapat mempengaruhi pengetahuan yang terbatas sehingga dapat berdampak pada pemilihan jenis makanan yang tidak tepat dan pola makan yang tidak terkontrol sehingga dapat mengakibatkan penyakit DM (Soekidjo, 2007).

Dari uraian fakta dan teori di atas dapat disimpulkan bahwa tingkat pendidikan dapat berpengaruh terhadap kejadian Diabetes Melitus. Hal ini dikarenakan sebagian besar pengetahuan seseorang berasal dari tingkat pendidikan yang diperoleh.

\section{Hubungan umur dengan kadar gula darah pada penderita Diabetes Melitus Tipe II}

Dari hasil uji statistik Paired $t$ test didapatkan nilai $\mathrm{p}$ value 0,000 yang lebih kecil dari $\alpha=0,05(0,000>0,05)$, sehingga dapat dikatakan bahwa $\mathrm{H}_{1}$ diterima yang berarti ada hubungan antara umur dengan kadar gula darah pada penderita Diabetes Melitus tipe II di Poli Penyakit Dalam RSUD dr. Iskak Tulungagung tahun 2017.

Berdasarkan penelitian Trisnawati at.al (2013), usia dapat meningkatkan kejadian DM tipe II karena penuaan dapat menurunkan sensitivitas insulin sehingga dapat mempengaruhi kadar glukosa dalam darah. Individu akan mengalami penyusutan sel $\beta$ pankreas yang progresif. Umumnya manusia mengalami penurunan fisiologis yang secara dramatis menurun dengan cepat pada usia setelah 40 tahun, salah satu yang berdampak adalah pada organ pankreas itu sendiri.

Dalam hal ini baik secara statistik maupun teori terdapat kesesuaian bahwa terdapat hubungan antara umur dengan kadar gula darah pada penderita Diabetes mellitus tipe II.

\section{Hubungan Status Gizi Berdasarkan Indeks Massa Tubuh Dengan Kadar Gula Darah pada Penderita Diabetes Melitus Tipe II}

Dari hasil uji statistik Paired t test didapatkan nilai $\mathrm{p}$ value 0,000 yang lebih kecil dari $\alpha=0,05(0,000>0,05)$, sehingga dapat dikatakan bahwa $\mathrm{H}_{1}$ diterima yang berarti ada hubungan antara status gizi dengan kadar gula darah pada penderita Diabetes Melitus tipe II di Poli Penyakit Dalam RSUD dr. Iskak Tulungagung tahun 2017.

Menurut TriExs (2009), masalah status gizi berlebih dan kegemukan/obesitas dapat memicu timbulnya peningkatan intoleransi glukosa karena tubuh seseorang menjadi gemuk 
lantaran terjadi penimbunan lemak, penimbunan terjadi karena makanan yang masuk ke dalam tubuh sangat berlebihan dan kelebihan tersebut tidak dibakar menjadi energi, sebab orang yang bersangkutan kurang beraktivitas, sedangkan masalah gizi kurang juga banyak menimbulkan peningkatan intoleransi glukosa. Teori Guyton (2007), obesitas merupakan faktor predisposisi kadar gula darah yang meningkat, hal ini dikarenakan sel-sel pulau langerhans menjadi kurang peka terhadap rangsangan akibat naiknya kadar gula dan menimbulkan resistensi reseptor insulin pada sel-sel di seluruh tubuh. Selain itu, obesitas akan terjadi peningkatan produksi resistin yang akan mendorong resistensi insulin dengan mengganggu kerja insulin. Sebaliknya adiponektin, adipokin lainnya akan meningkatkan sensitivitas terhadap insulin dengan meningkatkan efek insulin, tetapi pada obesitas terjadi penurunan hormon ini. Selain itu asam lemak yang dikeluarkan dari jaringan lemak dapat menumpuk abnormal di otot dan mengganggu kerja insulin otot. Pengendalian berat badan (pada pasien gemuk) dipercaya akan memperbaiki kadar glikemik jangka pendek dan mempunyai potensi meningkatkan kontrol metabolik jangka lama.( Sherwood ,2011)

Dari penelitian ini secara statistik menyatakan adanya hubungan antara status gizi dengan kadar gula darah pada penderita Diabetes Melitus Tipe II. Meskipun begitu ada beberapa faktor lain yang dapat menyebabkan tingginya ratarata kadar gula darah responden seperti aktivitas, kepatuhan minum obat, dan diit makanan yang dikonsumsi. sehingga secara fakta dan teori terdapat kesesuaian bahwa dengan adanya indeks massa tubuh yang berlebih maka kadar gula darah seseorang akan mengalami peningkatan. Resistensi insulin akan mengurangi pasokan glukosa ke dalam sel dan kemudian akan mendorong sel-sel beta pankreas untuk memproduksi dan mengeluarkan insulin tambahan. Dengan adanya kadar insulin yang tinggi pada umumnya dapat mengendalikan kadar gula darah untuk beberapa bulan. Namun, hal tersebut dapat menyebabkan sel-sel pada pankreas akan semakin menurun produktifitasnya karena terlalu berat bekerja. Dan akhirnya produksi insulin akan semakin lambat dan kemudian berhenti. Akibatnya, glukosa akan menumpuk di dalam darah dan menyebabkan kadar glukosa dalam darah menjadi tinggi (Brown, 2005).

\section{SIMPULAN}

1. Rata-rata umur responden di Poli Penyakit Dalam RSUD dr. Iskak Tulungagung Tahun 2017 adalah 57 tahun.

2. Rata-rata status gizi berdasarkan indeks massa tubuh pada penderita Diabetes Melitus tipe II di Poli Penyakit Dalam RSUD dr. Iskak Tulungagung Tahun 2017, dari 30 responden adalah 25,77 $\mathrm{Kg} / \mathrm{m}^{2}$ yang menunjukkan status gizi obesitas.

3. Rata-rata kadar gula darah pada penderita Diabetes Melitus tipe II di Poli Penyakit Dalam RSUD dr. Iskak Tulungagung Tahun 2017, dari 30 responden adalah 213,23 $\mathrm{mg} / \mathrm{dL}$ yang menunjukkan kadar gula darah tinggi.

4. Hasil uji statistik paired $t$ test didapatkan nilai $\mathrm{p}$ value 0,000 yang lebih kecil dari $\alpha=0,05(0,000<0,05)$, sehingga dapat dikatakan bahwa $\mathrm{H}_{1}$ diterima, $\mathrm{H}_{0}$ ditolak yang berarti ada hubungan antara umur dengan kadar gula darah pada penderita Diabetes Melitus tipe II di Poli Penyakit Dalam RSUD dr. Iskak Tulungagung tahun 2017.

5. Hasil uji statistik paired $t$ test didapatkan nilai $\mathrm{p}$ value 0,000 yang lebih kecil dari $\alpha=0,05(0,000<0,05)$, sehingga dapat dikatakan bahwa $\mathrm{H}_{1}$ diterima, $\mathrm{H}_{0}$ ditolak yang berarti ada hubungan antara status gizi dengan kadar gula darah pada penderita Diabetes Melitus tipe II di Poli 
Penyakit Dalam RSUD dr. Iskak Tulungagung tahun 2017.

\section{SARAN}

1. Bagi Ilmu Pengetahuan

a. Bagi Institusi Pendidikan Keperawatan

Dapat menjadi tambahan referensi dalam pengkayaan materi penyakit dalam khususnya auhan keperawatan penyekit diabetus mellitus.

b. Bagi Peneliti Selanjutnya

Bagi peneliti selanjutnya disarankan dapat melakukan penelitian dengan jumlah sampel yang lebih banyak dan lebih mempertimbangkan kelemahan penelitian yang dapat menjadi faktor perancu terhadap hasil penelitian seperti pola makan, sehingga hasil penelitian sesuai dengan yang diharapkan.

c. Bagi Responden

Bagi responden yang memiliki umur $>40$ tahun hendaknya lebih disiplin dalam melakukan pola hidup sehat, sedangkan responden dengan indeks massa tubuh $\geq 25 \mathrm{Kg} / \mathrm{m}^{2}$ diharapkan dapat mempertahankan berat badan rentang ideal melalui aktivitas olahraga atau mengurangi porsi makan, sehingga kadar gula darah tetap dalam rentang normal.

2. Bagi Pengembangan Program

a. Bagi Rumah Sakit

Diharapkan pihak rumah sakit dapat meningkatkan upaya preventif dan juga kuratif tentang faktor predisposisi yang memperberat penyakit Diabetus mellitus.

\section{DAFTAR PUSTAKA}

Abramovitz, M. 2005. Diseases And Disorders: Obesity. USA: Lucent Books.
American Diabetes Assosiation. 2010. Diagnosis And Classification of Diabetes Mellitus, Diabetes Care. USA 27:55.

American Diabetes Assosiation. 2015. Diagnosis And Classification of Diabetes Mellitus, Diabetes Care. USA 38:8-16.

Adnan, M., Tatik M., \& Joko T. I. 2013. Hubungan Indeks Massa Tubuh dengan Kadar Gula Darah Penderita Diabetes Melitus Tipe 2 Rawat Jalan di RS Tugurejo Semarang. Jurnal Gizi, Fakultas Ilmu Keperawatan dan Kesehatan: Universitas Muhammadiyah Semarang, Volume 2:18-20.

Almatsier. S. 2005. Prinsip Dasar Ilmu Gizi. Jakarta: PT Gramedia Pustaka Utama.

. 2009. Prinsip Dasar Ilmu Gizi. Jakarta: PT Gramedia Pustaka Utama.

Apriadji, W. H. 1986. Gizi Keluarga. Jakarta: PT Penebar Swadaya.

Arikunto, Suharsimi. 2006. Prosedur Penelitian Suatu Pendekatan Praktek Cetakan Ketigabelas. Jakarta: PT Rineka Cipta.

Arisman. 2010. Buku Ajar Ilmu Gizi Obesitas, Diabetes Mellitus, \& Dislipidemia. Jakarta: EGC.

Baliwati, Y.F, Ali K, \& Caroline M.D. 2004. Pengantar Pangan Dan Gizi. Jakarta: PT Penebar Swadaya.

Baradero, M. Mary W. D., \& Yakobus S. 2009. Asuhan Keperawatan Klien Gangguan Endokrin. Jakarta: EGC.

Black \& Hawks. 2009. Medical Surgical Nursing Clinical Management For Positive Outcomes. Elsevier Saunders.

Brown, Judith E dkk. 2005. Nutrition and The Elderly: Conditions and Intervention In U. Beate Krinkle dan Lori Roth-Yousey. USA: Thomson Wadsworth.

D'Adamo, Peter J. 2008. Diet Sehat Diabetes sesuai Golongan Darah. Yogyakarta: Delapratasa. 
Dalimartha, S. 2006. Ramuan Tradisional Untuk Pengobatan Diabetes Melitus. Jakarta: Penebar Swadaya.

Departemen Kesehatan RI. 2008. Pedoman Teknis Penemuan Dan Tatalaksana Penyakit Diabetes Melitus. Jakarta: Direktorat jenderal PP \& PL.

Dewi, R. K. 2014. Diabetes Bukan Untuk Ditakuti. Jakarta: FMedia.

Dorland. 2010. Kamus Kedokteran. Jakarta: EGC.

Gibson, R. S. 2005. Principles of Nutritional Assesment Second Edition. New York: Oxford University Press Inc.

Guyton, Arthur, Hall. 2007. Buku Ajar Fisiologi Kedokteran Edisi 9. Jakarta: EGC.

Hartriyanti, Y., \& Triyanti. 2007. Penilaian Status Gizi dalam Gizi dan Kesehatan Mastarakat. Jakarta: PT Raja Grafindo Persada.

Hidayat, A. 2012. Populasi dan Sampel. www//http:statistikian.com. Diakses tanggal 2 Januari 2017. Pukul 12.30 WIB.

Hill, J. O. 2005. Obesity: Etiology In Modern Nutrition In Health And Disease. USA: lipincot Williams \& Wilkins.

Ilmu Saudara. 2015. Pengertian Teknik Sampling dan Macam-macam Sampling Dalam Penelitian. www/http : ilmusaudara. com. Diakses tanggal 2 Januari 2017. Pukul 12.05 WIB.

Imam Soeharto. 2005. Serangan Jantung dan Stroke Hubungannya Dengan Lemak dan Kolesterol. Jakarta: Gramedia Pustaka Utama.

Irawan, D. 2010. Prevalensi dan Faktor Risiko Kejadian Diabetes Melitus Tipe 2 Di Daerah Urban Indonesia (Analisa Data Sekunder Riskesdas 2007). Thesis. Fakultas Kesehatan Masyarakat Indonesia Jakarta.

James, Joyce, Colin baker, \& Helen Swain. 2008. Prinsip-prinsip Sains
Untuk Keperawatan. Jakarta: Erlangga.

Kantachuvessiri A., et al. 2005. Factors Associated With Obesity Among Workers In A Metropolitan Waterworks Authority. Southest Asian J Trop Med Public Health. 36: 1057-1065.

Kariadi, S. H. 2009. Diabetes? Siapa Takut!! Panduan Lengkap Untuk Diabetisi, Keluarganya, dan Profesional Medis. Bandung: Qanita.

Lewis, Sharon L. et al. 2011. Medical Surgical Nursing Volume 1. USA: Elsevier Mosby.

Mansjoer, Arif, dkk. 2008. Kapita Selekta Kedokteran Edisi 3. Jakarta: Media Aesculap.

Mc. Wright, Bogdan. 2008. Panduan Bagi Penderita Diabetes. Jakarta: Prestasi Pustaka Publisher.

Nathan, David. 2009. Menaklukkan Diabetes, Terjemahan dari Harvard Medical School. BIP. Jakarta: Gramedia.

Nix, S. 2005. William's Basic Nutrition \& Diet Theraphy, Twenty Edition. USA: Elsevier Mosby Inc.

Notoatmojo, S. 2005. Metodologi Penelitian Kesehatan. Jakarta: Rineka Cipta.

Nurarif, A. H., \& Hardhi K. 2013. Aplikasi Asuhan Keperawatan Berdasarkan Diagnosa Medis dan Nanda NIC-NOC. Yogyakarta: Media Action Publishing.

Nursalam. 2003. Konsep dan Penerapan Metodologi Penelitian Ilmu Keperawatan. Jakarta: Salemba Medika. 2008. Konsep dan Penerapan Metodologi Penelitian Ilmu Keperawatan. Jakarta: Salemba Medika.

PERKENI, 2011. Konsensus Pengelolaan dan Pencegahan Diabetes Melitus Tipe 2 di Indonesia. www.perkeni.org. Diakses tanggal 1 Januari 2017. Pukul 14.05 WIB. 
Priasmara, Yunan Dian. 2015. Hubungan Indeks Massa Tubuh dengan Kadar Gula Darah pada Lansia di Kota Semarang. Skripsi, Fakultas Ilmu Keolahragaan:Universitas Negeri Semarang.

Riyadi, S., \& Sukarmin. 2008. Asuhan Keperawatan pada Pasien dengan Gangguan Eksokrin dan Endokrin pada Pankreas. Yogyakarta: Graha Ilmu.

Soegondo, S., \& Kartini S. 2008. Diabetes Melitus Kencing Manis Sakit Gula. Jakarta: Balai Penerbit FKUI.

Riyanto, A. 2011. Pengolahan dan Analisis Data Kesehatan. Yogyakarta: Nuha Medika.

Robbins, dkk. 2007. Buku Ajar Patologi Volume 2 Edisi 7. Jakarta: EGC.

Rutoto, Sabar. 2007. Pengantar Metodologi Penelitian. FKIP: Universitas Muria Kudus.

Setiadi. 2007. Konsep Dan Penulisan Riset Kepearawatan. Yogyakarta: Graha Ilmu.

Sherwood, L. 2011. Fisiologi Manusia Dari Sel Ke Sistem. Jakarta: EGC.

Smeltzer, Suzanne C. \& Bare, Brenda G. 2002. Buku Ajar Keperawatam Medikal Bedah Brunner \& Suddarth (Edisi 8 Vol. 12). Jakarta: EGC.

Soegih, R., \& Kunkun K. 2009. Obesitas Permasalahan dan Terapi Praktis. Jakarta: Sagung Seto.

Soewondo P. \& Subekti I. 2007. Penatalaksanaan Diabetes Melitus Terpadu. Jakarta: Balai Penerbit FKUI.

Sornoza O., Ariana K, Mandoza S., \& Humberto D. 2012. Diabetes Mellitus $Y$ Sus Complicaciones En Los Paciences Atendidos En La. Unidad Medica Universitaria de portoviejo Mayo Septiembre 2011.

Sugi. 2012. Pengertian Populasi dan Sampel dalam Penelitian. www//http: sugithewae. wordpress.com. Diakses tanggal 2 Januari 2017. Pukul 13.30 WIB.
Sugiyono. 2007. Metode Penelitian Pendidikan Pendekatan Kuantitatif, Kualitatif. Bandung: Alfabeta.

2010. Statistika Untuk

Penelitian. Bandung: Alfabeta.

Sugondo, S. 2006. Obesitas. Editor Sudoyo. W, Setiyohadi. B, Alwi.I, Simandibrata. K, Setiati. S. Bahan Ajar Ilmu Penyakit Dalam Jilid III edisi IV. Jakarta: Pusat Penerbitan Departemen Ilmu Penyakit Dalam Fakultas Kedokteran Universitas Indonesia.

Sukmadinata, Nana Syaodih. 2010. Metode Penelitian Pendidikan. Bandung: PT Remaja Rosdakarya.

Suyono, S. 2007. Buku Ajar Ilmu Penyakit Dalam Jilid III Edisi IV, Diabetes Mellitus di Indonesia. Jakarta: Balai Penerbit Fakultas Kedokteran UI.

Sulistianingrum, Nita D. 2010. Hubungan Indeks Massa Tubuh dan Rasio Lingkar Pinggang Pinggul dengan Kadar Gula Darah Puasa. Skripsi, Fakultas Kedokteran: Universitas Sebelas Maret Surakarta.

Supariasa, I. D. N. 2001. Penilaian Status Gizi. Jakarta: Buku Kedokteran EGC. 2014. Penilaian Status Gizi. Jakarta: Buku Kedokteran EGC.

Susilo, Yekti \& Ari W. 2011. Cara Jitu Mengatasi Diabetes Melitus (Kencing Manis). Yogyakarta: Andi Offset.

Tandra, H. 2013. Life Healthy With Diabetes-Diabetes Mengapa dan Bagaimana. Yogyakarta: Rapha Publishing. 2008. Segala Sesuatu yang Harus Anda Ketahui Tentang Diabetes Panduan Lengkap Mengenal dan Mengatasi Diabetes dengan Cepat dan Mudah. Jakarta: Gramedia Pustaka Utama.

Tarwoto, W., dkk. 2012. Keperawatan Medikal Bedah Gangguan Sistem Endokrin. Jakarta: Trans Info Media.

Theresia. T. L. 2012. Hubungan Overweight dengan Peningkatan Kadar Gula Darah Pada Pedagang Pusat Pasar Medan. Fakultas 
Kedokteran Universitas Sumatera Utara Medan.

TriExs. 2009. Having Fun With Diabetes Melitus. Bandung: PT TriExs Media.

Trisnawati. 2013. Faktor Risiko Kejadian Diabetes Mellitus Tipe 2 Di puskesmas Kecamatan Cengkareng Jakarta Barat. Jurnal Ilmiah Kesehatan Volume 5, No 1. http // lp3m. thamrin. ac. id/ upload / artikel\% 202. \%20vol\% 205\% 20n0\% 201_shara. pdf. Diakses tanggal 12 Maret 2017 Pukul 13.45 WIB.

Wardlaw, G. M. \& Jeffrey, S. H. 2007. Perspectives In Nutrition Seventh Edition. New York: MC Graw Hill Companies Inc.

Yuliana, Elin \& Andrajat R. 2009. ISO Fakrmakoterapi. Jakarta: ISFI. 